Boynton, C. K., O. C. Lansdorp, N. A. Mahony, and T. D. Williams. 2021. Minor interspecies differences in breeding phenology and productivity between two co-occurring aerial insectivores. Avian Conservation and Ecology 16(2):27. https://doi.org/10.5751/ACE-02001-160227

Copyright $(C) 2021$ by the author(s). Published here under license by the Resilience Alliance.

Research Paper

\title{
Minor interspecies differences in breeding phenology and productivity between two co-occurring aerial insectivores
}

\author{
Chloe K. Boynton ${ }^{1,2}$, Olga C. Lansdorp ${ }^{2}$, Nancy A. Mahony ${ }^{3}$ and Tony D. Williams ${ }^{2}$ \\ ${ }^{1}$ Environment and Climate Change Canada, Canadian Wildlife Service, Delta, BC, Canada, ${ }^{2}$ Department of Biological Sciences, \\ Simon Fraser University, Burnaby, BC, Canada, ${ }^{3}$ Environment and Climate Change Canada, Wildlife Research Division, \\ Edmonton, AB, Canada
}

\begin{abstract}
Aerial insectivore populations have declined significantly across Canada for the last fifty years. Although there are several suggested drivers of these population declines, including agricultural intensification, not all species show similar spatiotemporal population trends. Therefore, comparing interspecies differences in breeding productivity on the breeding grounds is vital to understand what is driving population variation among aerial insectivores. We examined breeding productivity and phenology in relation to habitat, weather, and insect availability for two co-occurring swallow species, Tree Swallow (Tachinyeta bicolor; -2.79 regional annual trend index) and Barn Swallow (Hirundo rustica; -3.33 regional annual trend index) over four years on the southern coast of British Columbia, Canada. We found only minor interspecies differences in breeding productivity (brood size, fledge success) comparing first broods, although the Barn Swallow is double-brooded, suggesting higher potential productivity than in the Tree Swallow. However, Tree Swallows had larger clutches, earlier lay dates, and more rapid cumulative laying than Barn Swallows. There was little effect of habitat on breeding productivity or phenology for either species, and we found no significant difference in total insect abundance between crop and pasture habitats. Overall, our study suggests there is little interspecies variation in breeding productivity for first broods between these co-occurring aerial insectivores in British Columbia. Given the higher propensity for double brooding and no differences in brood size or fledging success, Barn Swallows in this region may, in fact, have higher annual productivity than Tree Swallows, despite a more steeply declining regional population trend, suggesting that declines are caused by factors operating outside the breeding grounds or during post-breeding.
\end{abstract}

\section{Différences interspécifiques mineures dans la phénologie de nidification et la productivité de deux insectivores aériens cooccurrents}

RÉSUMÉ. Les populations d'insectivores aériens ont diminué de façon importante au Canada au cours des cinquante dernières années. Bien que plusieurs facteurs soient avancés pour expliquer ces baisses de population, notamment l'intensification de l'agriculture, les espèces ne présentent pas toutes des tendances spatio-temporelles similaires. Par conséquent, il est essentiel de comparer les différences entre les espèces en matière de productivité sur les lieux de nidification si on veut comprendre ce qui fait varier les populations d'insectivores aériens. Nous avons examiné la productivité et la phénologie en fonction del'habitat, des conditions météorologiques et de la disponibilité d'insectes pour deux espèces d'hirondelles cooccurrentes, l'Hirondelle bicolore (Tachinyeta bicolor; indice de tendance annuelle régionale de -2,79) et l'Hirondelle rustique (Hirundo rustica; indice de tendance annuelle régionale de -3,33) pendant quatre ans sur la côte sud de la Colombie-Britannique, au Canada. Nous n'avons trouvé que des différences mineures entre ces deux espèces quant à la productivité (taille de la ponte, succès des jeunes à l'envol) en comparant la première ponte; or, l'Hirondelle rustique procède à une seconde ponte, ce qui laisse croire qu'elle aurait une productivité potentielle plus élevée que celle de l'Hirondelle bicolore. Toutefois, les Hirondelles bicolores avaient de plus grandes couvées, des dates de ponte plus hâtives et une ponte cumulative plus rapide que les Hirondelles rustiques. L'habitat a eu peu d'effets sur la productivité ou la phénologie de l'une ou l'autre des espèces, et nous n'avons trouvé aucune différence significative dans l'abondance totale d'insectes entre les milieux cultivés et les pâturages. Dans l'ensemble, nos résultats indiquent qu'il y a peu de variation interspécifique en matière de productivité pour la première ponte entre ces insectivores aériens cooccurrents en Colombie-Britannique. Étant donné leur propension plus élevée de faire une seconde ponte et l'absence de différences dans la taille de ponte ou le succès des jeunes à l'envol, il est possible que les Hirondelles rustiques de cette région aient, en fait, une productivité annuelle plus élevée que celle des Hirondelles bicolores, malgré une tendance régionale à la baisse plus marquée, résultat qui laisse supposer que les baisses sont causées par des facteurs agissant ailleurs que sur les aires de nidification ou pendant la période suivant la reproduction.

Key Words: Barn Swallow; breeding productivity; habitat; interspecies variation; phenology; Tree Swallow

Correspondent author: Chloe K Boynton, chloe.boynton@ec.gc.ca, chloe.boynton@ec.gc.ca 


\section{INTRODUCTION}

Several species of aerial insectivores (swallows, swifts, nightjars, some flycatcher species) have been steeply declining across North America since the 1980s (Nebel et al. 2010, Smith et al. 2015). In Canada, this guild has declined more than any other group of birds since 1970, including grassland birds and shorebirds (North American Bird Conservation Initiative Canada 2019, Rosenberg et al. 2019). Although the causes of these population declines are not fully resolved, agricultural intensification (Benton et al. 2002, Paquette et al. 2013), climate and weather effects (García-Pérez et al. 2014), associated shifts in prey abundance (Nocera et al. 2012), and pesticide use (e.g., neonicotinoids; Hallmann et al. 2014) have all been suggested as mechanisms behind these population declines. However, a recent review by Spiller and Dettmers (2019) suggests that multiple drivers, including those noted previously, are causing aerial insectivore declines across North America.

Aerial insectivorous species share several biological traits as a guild. One of the main commonalities is their foraging biology, specifically catching aerial insects on the wing. Even though aerial insectivores use a variety of different nesting strategies (e. g., building open-cupped nests in anthropogenic structures vs. a secondary cavity-nesting strategy), they often occupy similar habitats and largely breed over the same geographic range, and the majority of populations migrate. Therefore, it is surprising that few studies have simultaneously considered phenology and breeding productivity of multiple aerial insectivore species at the same breeding location in relation to land use and climate (but see Ramstack et al. 1998, Imlay et al. 2018), especially given that this knowledge could help elucidate drivers of variation in spatiotemporal patterns of population change that are reported in North America (Nebel et al. 2010, Michel et al. 2016). For example, among co-occurring aerial insectivorous species, there is evidence of dissimilar spatiotemporal population trajectories, e.g., Tree Swallow (Tachycineta bicolor) and Barn Swallow (Hirundo rustica) in the Pacific Northwest region of Canada (Michel et al. 2016). The Tree Swallow has experienced a smaller decline in annual abundance from 1970-2019 on the southern coast of British Columbia (hereafter BC; -2.79 annual trend index, $95 \%$ confidence interval $[\mathrm{CI}]-4.29$ to -1.14$)$ ) compared to the Barn Swallow ( -3.33 annual trend index, CI -4.42 to -2.24; Smith et al. 2019). Contemporary trends (2009-2019) show an increase in the Tree Swallow, whereas the Barn Swallow is still declining $(1.81, \mathrm{CI}-2.95$ to 6.54 vs. $-1.06, \mathrm{CI}-5.11$ to 2.74 , respectively). This pattern is also seen across Canada in both long-term and contemporary trends (Tree Swallow 19702019: 0.86, CI -2.6 to 0.033; 2009-2019: 0.434, CI -1.96 to 3.83 vs. Barn Swallow 1970-2019: -2.34, CI -2.66 to -2.05; 20092019: -0.121 , CI -1.08 to 0.877$)$. Tree Swallows show strong trends in breeding population decline in the northeast, but are declining less steeply in the rest of North America, whereas Barn Swallows show an overall greater decline across North America (Michel et al. 2016). The Barn Swallow is currently listed as Threatened in Canada under the Species at Risk Act (Government of Canada 2017), whereas the Tree Swallow has not received any at-risk designation.

The difference in conservation status and population trends between Tree Swallows and Barn Swallows suggests that there may be highly variable and complex spatiotemporal patterns of population change. Therefore, an exploration is necessary to determine whether this variation is related to region-specific interactions of breeding phenology, productivity, and environmental conditions such as changing weather, insect availability, or habitat. There are several key species differences that could also be driving variation in population declines in Canada and, more specifically, on the southern coast of British Columbia. One difference is the variation in prey type consumed; Tree Swallows forage primarily on aquatic insects (Winkler et al. 2020), in addition to Diptera (Paquette et al. 2014), whereas Barn Swallows are more opportunistic, although they commonly consume Diptera and other terrestrial insects (McClenaghan et al. 2019, Brown and Brown 2020). Furthermore, although both species migrate, Barn Swallows winter as far south as southern South America, although western breeding individuals (from Washington state, USA and Saskatchewan, Canada) are found wintering further north, from Oregon to Colombia (Hobson et al. 2015). In contrast, Tree Swallows typically winter in southern United States, Mexico, the Caribbean, and central America (Knight et al. 2018, Winkler et al. 2020). Barn Swallows arrive on their breeding grounds on the southern coast of British Columbia in late March to early April, whereas Tree Swallows arrive earlier, from mid-February to the end of March (Campbell et al. 1997), although some individuals arrive in April (Gow et al. 2019a). Despite these species differences, few studies focus on coexisting swallows in the same breeding location, which may help to elucidate whether local drivers are contributing to the differential declines, although local population trends can be driven by multiple demographic rates such as immigrationemigration and survival (Weegman et al. 2017, Cox et al. 2018).

We quantified variation in breeding productivity and phenology of two co-occurring aerial insectivores, Barn Swallow and Tree Swallow, in relation to habitat, insect availability, and weather over four years near Vancouver, BC. We studied both species at the same 11 locations across three different habitat types (crop, pasture, and nonagricultural). We tested the hypothesis that the greater rate of decline in Barn Swallows in the region is related to habitat and environmental factors operating on breeding grounds. We predicted that (1) Barn Swallows will breed later (resulting in a seasonal decline in reproductive success; Verhulst et al. 1995) and have lower breeding productivity (smaller clutch size, lower fledging success, and smaller brood size at fledging); (2) both species will have higher breeding productivity on livestock farms than elsewhere because of greater insect abundance in pasture habitats, and this effect will be strongest for Barn Swallows; and (3) Barn Swallows will not respond or will respond negatively compared to Tree Swallows to annual variation in temperature, rainfall, or wind, and in terms of the effects these climate variables have on breeding phenology or productivity.

\section{METHODS}

\section{Study area}

Field work was conducted near Vancouver, BC, Canada $\left(49^{\circ}\right.$ $10^{\prime} 8.15^{\prime}$ N, $123^{\circ} 5$ '58.60" W) from 2013 to 2016. In 2013, study locations were chosen based on the presence of Barn Swallow 
nests, typically located in or on barns or other buildings (range of $1-5$ buildings with nests per location), with a minimum distance between locations of $500 \mathrm{~m}$. Within each location, the maximum distance between Barn Swallow nests was approximately $130 \mathrm{~m}$. We put up Tree Swallow nest boxes 15-20 m apart around each location in $2013(N=10$ for all locations initially, except Sea Island $N=8$ ). A total of 11 locations were used each year, and each location was categorized into three landscape types: agriculture with crops, including vegetables, grains, and fruits (hereafter, crop; $N=4$ ); agriculture with livestock, including both cows and horses (hereafter, pasture; $N=4$ ); and nonagriculture, which occurred in more urban areas, but were not accessible to the public and included a gated park, a private marina, and a municipal works yard $(N=3)$. The number of nests per location and year varied, with 1046 active nests (nests with at least one egg) for Barn Swallows $($ crop $=343$, pasture $=584$, nonagriculture $=119)$ and 219 active nests for Tree Swallows $($ crop $=85$, pasture $=123$, nonagriculture $=11$ ) for all years and locations combined.

\section{Nest monitoring}

Barn Swallow nests were checked twice per week from late April to mid-August, and Tree Swallow nests were checked twice per week from late April to mid- to late July in all four years. We recorded lay date (date the first egg was laid), clutch size (assumed 1 egg laid per day for both species), hatch date (day 0), brood size, fledging success, evidence of predation, and mite presence in nests. To determine hatch date, we used an aging guide from Morales Fernaz et al. (2012) for Barn Swallow nestlings, and a current (at the time) growth guide from a Tree Swallow Project website for Tree Swallow nestlings. For both species, we defined nests as successful if nestlings were in the nest on day 18 (minimum fledging age in both species) or if nests were empty after day 18 and there was evidence of successful fledging (such as feces in or below the nest). Nest predation was assumed if eggs or chicks disappeared before day 18 for Barn Swallows (because of their use of open-cup nests), and nest success was unknown if there was no sign of predation or successful fledge before the minimum fledge age for Tree Swallows, and after the minimum fledge age (day 18) for both species. We estimated reproductive success in two ways, by examining the brood size (number of nestlings) within a nest (best estimate closest to fledge date) for successfully fledged nests, and the fledging success of each nest (at least one chick left the nest alive; 1 = successful nest, 0 = failed nest).

\section{Insect data and collection}

For insect sampling, we used passive wind nets (Hussell and Quinney 1987) set up in the same spot at each location, placed away from obstructions, and designed to rotate on a pole in the direction of the wind, with the mouth of the net $1 \mathrm{~m}$ above the vegetation to capture aerial insects. Jars containing 7:3 alcohol: water were used to collect the insects. Jars were replaced once per week for the duration of the study; for this analysis, we used samples collected during 13-18 June, which corresponds with the peak period (in each year) for the first brood of nestlings for both species. For this period, we had the following samples for each habitat across the 4 years: crop, four sites and 28 total net/day samples; pasture, four sites and 28 total net/day samples; nonagriculture, three sites and 19 total net/day samples. Insect abundance estimated for one net was positively correlated with insect abundance from a second net at the same location $\left(r^{2}=\right.$ $0.51, P<0.001$ ), so we used data from both nets per site when available. Insect samples were counted and sorted to taxonomic order using a dissecting microscope and taxonomic keys and pictorial guides (Triplehorn et al. 2005; BugGuide: overview of orders of insects http://bugguide.net/node/view/222292, University of Queensland: insect orders https://www.discoverlife.org/ $\mathrm{mp} / 20 \mathrm{q}$ ?guide=Insect_orders), current (at the time) Internetbased guides of insect orders from the American Museum of Natural History and the University of Guelph, and additional assistance from Simon Fraser University entomologists. We did not include insect fragments (legs, heads, wings) in our final count.

\section{Weather data}

We obtained weather data from Environment and Climate Change Canada (Government of Canada 2019) for all four years (2013-2016) from a Vancouver weather station (YVR Airport, $49^{\circ} 11^{\prime} 42.000^{\prime} \mathrm{N}, 123^{\circ} 10^{\prime} 55.000^{\prime} \mathrm{W}$, elevation $4.30 \mathrm{~m}$ ). We used data for average daily temperature $\left({ }^{\circ} \mathrm{C}\right)$, average daily precipitation $(\mathrm{mm})$, and average daily wind speed $(\mathrm{km} / \mathrm{h})$ as variables to represent local weather (Cox et al. 2019, Facey et al. 2020). We calculated averages for (1) the pre-laying period, either 2 or $4 \mathrm{wk}$ (to account for the nest-building period and arrival on breeding grounds) before the first egg date for each species in each year, and (2) for the month of June, which coincided with the main chick-rearing period for first broods in both species.

\section{Statistical analysis}

Modeling and statistical analysis were performed in RStudio 1.0.136 (RStudio Team 2016) using R 3.5.2 (R Core Team 2018). Our main analysis focused on species differences in lay date (Julian date; day 1 = 1 January), clutch size, brood size at fledging, and fledging success in 2013-2016 (4 yr). This analysis was restricted to (1) crop and pasture habitats only because most boxes in nonagricultural habitats were used by Violet-green Swallow (Tachycineta thalassina), limiting Tree Swallow data to only one of the four years in this habitat; and (2) first broods because Tree Swallows are typically single-brooded, whereas Barn Swallows are double-brooded (see Results: Breeding phenology). True "first" clutches or broods for both species were defined by a set of rules via back-calculating estimated lay dates (first egg dates) when they were unknown but hatch dates were known, and by assigning clutches or broods as first, replacement, or second. We also report data for second broods in Barn Swallows.

We used linear mixed effects models (nlme package; Pinheiro et al. 2020) and initially ran full models with lay date or clutch size as the dependent variable, species, year, and habitat (crop/pasture) as main effects, all two-way and three-way interactions, and individual nest identity (ID) nested within location as a random effect. We estimated overall main effects using ANOVA (fit = marginal), and calculated least-squares means and conducted pair-wise multiple comparisons with Tukey-adjusted $P$ values. For clutch size and brood size at fledging, we restricted analysis to nests for which these variables were known with certainty, and we included lay date as a covariate. For brood size at fledging (of only successful nests), we only compared 3 years of data (20142016), because in 2013, there were only three Tree Swallow nests with known brood size, all in crop habitat. 
Table 1. Julian lay date (clutch initiation date) for first broods of Barn Swallow and Tree Swallow for 2013 to 2016 across habitat types, habitat type average, and minimum and maximum lay date, as well as overall species averages. Values are mean lay date \pm standard deviation, with sample size in parentheses.

\begin{tabular}{|c|c|c|c|c|c|c|c|}
\hline \multirow[b]{2}{*}{ Species } & \multirow[b]{2}{*}{ Year } & \multicolumn{3}{|c|}{ Habitat type } & \multirow[b]{2}{*}{ Average lay date } & \multirow[b]{2}{*}{$\begin{array}{c}\text { Minimum lay } \\
\text { date }\end{array}$} & \multirow[b]{2}{*}{ Maximum lay date } \\
\hline & & Crop & Pasture & Nonagricultural & & & \\
\hline \multirow[t]{5}{*}{ Barn Swallow } & 2013 & $\begin{array}{c}144.2 \pm 6.4 \\
\quad(39)\end{array}$ & $\begin{array}{l}145.1 \pm 6.2 \\
\quad(57)\end{array}$ & $\begin{array}{c}152.9 \pm 6.0 \\
(10)\end{array}$ & $\begin{array}{l}145.5 \pm 6.7 \\
\quad(106)\end{array}$ & 129 & 157 \\
\hline & 2014 & $\begin{array}{c}142.0 \pm 6.8 \\
(48)\end{array}$ & $\begin{array}{c}141.7 \pm 6.2 \\
\quad(72)\end{array}$ & $\begin{array}{c}146.1 \pm 4.9 \\
\quad(14)\end{array}$ & $\begin{array}{c}142.3 \pm 6.4 \\
\quad(134)\end{array}$ & 131 & 154 \\
\hline & 2015 & $\begin{array}{c}140.8 \pm 5.7 \\
\quad(48)\end{array}$ & $\begin{array}{c}140.3 \pm 5.9 \\
\quad(77)\end{array}$ & $\begin{array}{c}144.9 \pm 7.2 \\
(12)\end{array}$ & $\begin{array}{l}140.9 \pm 6.0 \\
\quad(137)\end{array}$ & 127 & 152 \\
\hline & 2016 & $\begin{array}{c}138.9 \pm 5.8 \\
(35)\end{array}$ & $\begin{array}{l}138.5 \pm 6.7 \\
\quad(55)\end{array}$ & $\begin{array}{c}138.2 \pm 1.9 \\
(6)\end{array}$ & $\begin{array}{c}138.6 \pm 6.1 \\
(96)\end{array}$ & 124 & 150 \\
\hline & Average & $\begin{array}{l}141.5 \pm 6.4 \\
\quad(170)\end{array}$ & $\begin{array}{l}141.4 \pm 6.6 \\
\quad(261)\end{array}$ & $\begin{array}{c}146.3 \pm 7.1 \\
(42)\end{array}$ & $\begin{array}{c}141.9 \pm 6.7 \\
(473)\end{array}$ & 127.8 & 153.3 \\
\hline \multirow[t]{5}{*}{ Tree Swallow } & 2013 & $\begin{array}{c}138.6 \pm 1.7 \\
(7)\end{array}$ & $\begin{array}{c}132.7 \pm 3.4 \\
(4)\end{array}$ & N/A & $\begin{array}{c}136.5 \pm 3.7 \\
\text { (11) }\end{array}$ & 128 & 141 \\
\hline & 2014 & $\begin{array}{c}136.0 \pm 1.9 \\
(15)\end{array}$ & $\begin{array}{c}135.7 \pm 3.4 \\
(27)\end{array}$ & $\begin{array}{c}141.0 \pm 2.0 \\
\text { (4) }\end{array}$ & $\begin{array}{c}136.3 \pm 3.2 \\
(46)\end{array}$ & 130 & 142 \\
\hline & 2015 & $\begin{array}{c}133.3 \pm 3.4 \\
\quad(18)\end{array}$ & $\begin{array}{c}133.4 \pm 3.8 \\
(31)\end{array}$ & N/A & $\begin{array}{c}133.3 \pm 3.6 \\
(49)\end{array}$ & 125 & 142 \\
\hline & 2016 & $\begin{array}{l}129.7 \pm 5.2 \\
\quad(23)\end{array}$ & $\begin{array}{c}130.2 \pm 4.1 \\
\quad(32)\end{array}$ & N/A & $\begin{array}{c}129.9 \pm 4.6 \\
(55)\end{array}$ & 122 & 142 \\
\hline & Average & $\begin{array}{c}133.2 \pm 4.9 \\
(63)\end{array}$ & $\begin{array}{c}132.9 \pm 4.4 \\
(94)\end{array}$ & $\begin{array}{c}141.0 \pm 2.0 \\
(4)\end{array}$ & $\begin{array}{c}133.2 \pm 4.7 \\
(161)\end{array}$ & 126.3 & 141.8 \\
\hline
\end{tabular}

To test for habitat effects, including nonagriculture habitat, we compared lay date, clutch size, and brood size at fledging in Barn Swallows using data for 2013-2016 with year, habitat, and year $\times$ habitat as main effects, and individual nest ID nested within location as a random effect. For Tree Swallows, we compared lay date, clutch size, and brood size at fledging among all three habitats using data for 2014 only.

We calculated fledging success based on successful fledging of $1+$ chick $(1=$ successful nest, $0=$ failed nest $)$. We analyzed these data using logistic regression, with fledging success as the response variable.

We ran linear effects models on the total number of insects with year and habitat as main effects, a year $\times$ habitat interaction, and individual net ID nested within location as a random effect. The total number of insects was $\log _{10}$ transformed for analysis, but we report raw data for ease of interpretation.

For weather data, we first tested for annual variation in each weather variable (temperature, rainfall, wind speed) for the prelaying periods ( 2 and 4 weeks before the first recorded egg) and the chick-rearing period (June) using ANOVA. We then compared the averages for each 2- and 4-week weather variable with average lay date and clutch size for each species and year combination and June weather with brood size for each species. We tested average weather and breeding variables over all locations for each year with species pooled ( $N=44$ for each species) using linear mixed effects models, with breeding variables as dependent variables, and average weather variables as main effects, with a species interaction, and location as a random factor.

\section{RESULTS}

\section{Breeding phenology}

Barn Swallow lay dates displayed a strong bimodal pattern in all four years, with first peaks around 20 May (Julian date 140; range 137-142) and second peaks (second clutches) around 7 July (188; range 181-191). In contrast, Tree Swallows showed a unimodal pattern of lay dates in each year, with a peak around 14 May (134; range 130-138; Fig. 1). Barn Swallows initiated first broods over a period of 23-28 d, whereas Tree Swallows initiated first broods over only 12-20 d (Table 1). Barn Swallows initiated second clutches up to 3 August (latest lay date from all active nests), whereas Tree Swallows only initiated clutches until 2 July. The total range of lay dates over which nests were initiated, based on 5-95\% quantiles, was therefore much longer in Barn Swallows (mean 63 d, range 60-67 d) compared to Tree Swallows (mean 39 $\mathrm{d}$, range $31-53 \mathrm{~d})$.

\section{Variation in lay date}

Lay date was independent of habitat (crop vs. pasture, $F_{1,100}=$ $0.00, P>0.95)$, but there was a significant main effect of species $\left(F_{1,301}=169.6, P<0.001\right)$ and year $\left(F_{3,171}=33.0, P<0.001\right)$. The species $\times$ year interaction was not significant $\left(F_{3,171}=1.66, P>\right.$ $0.15)$, and no other interactions were significant $(P>0.20$ in all cases; Table 1). Tree Swallows laid earlier on average than Barn Swallows in each of the four years: by 8.7, 6.1, 7.5, and $8.9 \mathrm{~d}$ in 2013-2016, respectively (Fig. $2 ; P<0.001$ in all cases; mean for all years $7.8 \pm 0.7 \mathrm{~d}$ earlier; $\left.F_{1,301}=169.55, P<0.001\right)$.

In contrast to variation in mean lay date, the first egg dates (minimum lay date) only differed by $1-2 \mathrm{~d}$ between species in each year (Table 1). However, across all first broods, Tree Swallows laid more synchronously after initiation of egg-laying compared to Barn Swallows (i.e., more rapid cumulative laying; Fig. 3). Among 
Fig. 1. Number of nests by lay date from 2013-2016 for Tree Swallows (top row) and Barn Swallows (bottom row). Julian date $1=1$ January. Bars show all active nests for both species, including replacement and second broods.

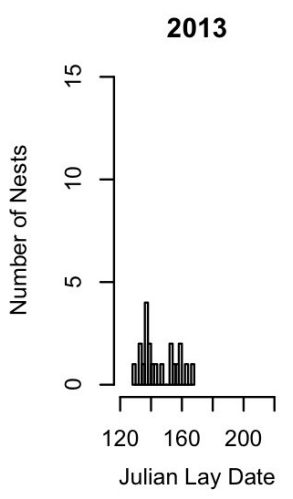

2013

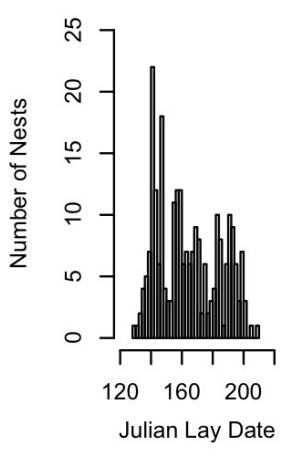

2014

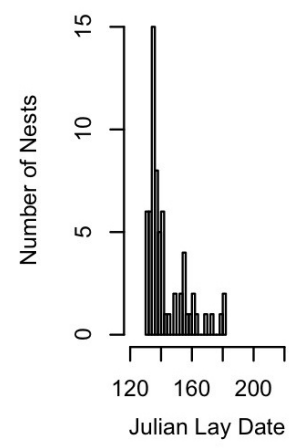

2014

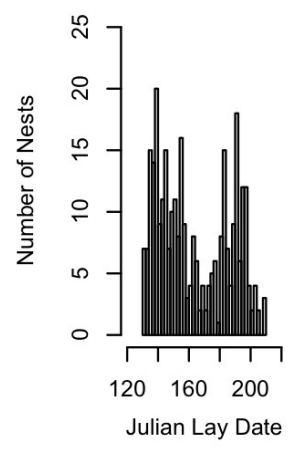

2015

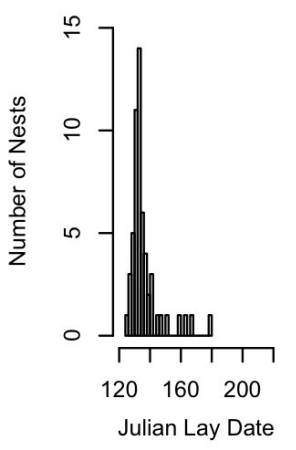

2015

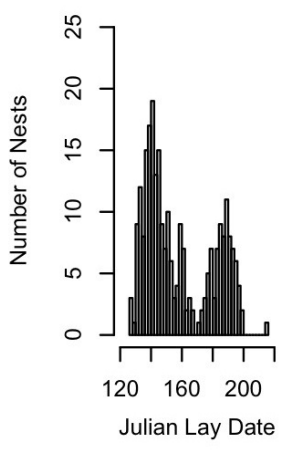

2016

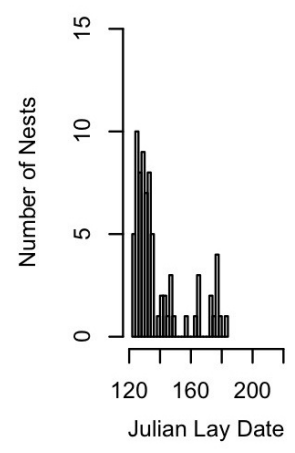

2016

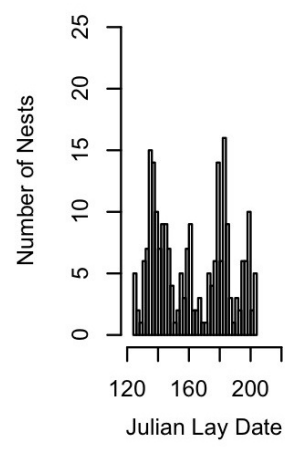

Fig. 2. Box plots of Julian lay date (clutch initiation dates) for first broods of Barn Swallows (dark grey) and Tree Swallows (light grey) from 2013-2016. Julian date $1=1$ January. Boxes represent the first and third quartiles, bolded lines represent the median, and whiskers represent upper and lower limits.

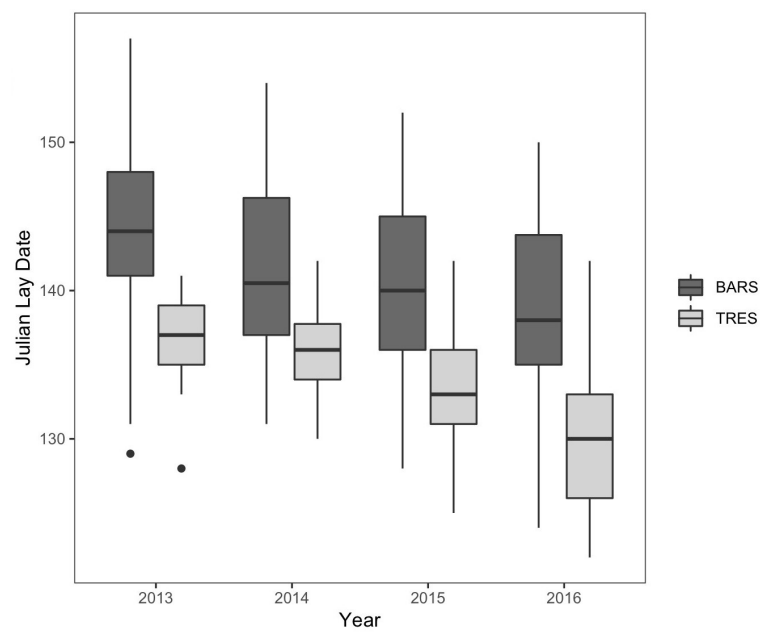

Fig. 3. Cumulative numbers of nests (\% of total nests in each year) for all first broods of Barn Swallows (black) and Tree Swallows (grey) for all four years of study (2013-2016) by the relative Julian lay date. Julian date $1=1$ January. Lines are nonparametric local regressions. Shaded areas represent 95\% confidence intervals.
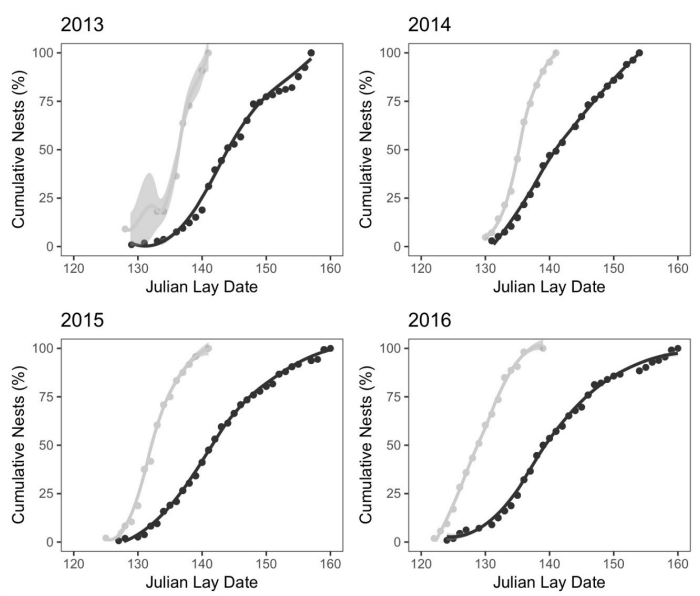
years, the coefficient of variation for lay date was $4.5-7.3 \%$ in Barn Swallows compared with 2.3-3.5\% for Tree Swallows.

\section{Clutch size variation}

In the full model for clutch size, there were significant interactions for species $\times$ year $\left(F_{3,148}=5.0, P=0.003\right)$ and habitat $\times$ species $\times$ year $\left(F_{3,148}=3.59, P=0.015\right)$. Therefore, we analyzed clutch size for each habitat separately with species, year, and species $\times$ year as main effects (Table A1.1 in Appendix 1). In crop habitat, clutch size varied by species $\left(F_{1,130}=27.4, P<0.001\right)$ but was independent of year $\left(F_{3,53}=1.7, P>0.015\right)$ and species $\times$ year $\left(F_{3,53}=1.7, P>0.015\right.$; controlling for laying date, $\left.P<0.01\right)$. Overall, Tree Swallows had a larger mean clutch size than did Barn Swallows: $5.2 \pm 0.9$ eggs vs. $4.7 \pm 0.7$ eggs $\left(t_{53}=-2.47, P=\right.$ 0.017).

In pasture habitat, there was a significant species $\times$ year interaction for clutch size $\left(F_{3.94}=7.22, P<0.001\right)$, so we compared species differences by year. Clutch size was larger in Tree Swallows than in Barn Swallows in only one year $\left(2016, t_{94}=4.23, P<\right.$ $0.01)$, with no species differences in the other three years $(P>0.25$ in all cases; Table 2).

Barn Swallow second clutches had an average clutch size of 4.09 $( \pm 0.84)$ across habitats and years.

Table 2. Average clutch size (number of eggs) for first broods of Barn Swallow and Tree Swallow for 2013 to 2016 across habitat types, habitat type average, and overall species averages. Values are mean clutch size \pm standard deviation, with sample size in parentheses.

\begin{tabular}{|c|c|c|c|c|c|}
\hline \multirow[b]{2}{*}{ Species } & \multirow[b]{2}{*}{ Year } & \multicolumn{3}{|c|}{ Habitat type } & \multirow[b]{2}{*}{ Average } \\
\hline & & Crop & Pasture & $\begin{array}{c}\text { Nonagric- } \\
\text { ultural }\end{array}$ & \\
\hline \multirow[t]{5}{*}{$\begin{array}{l}\text { Barn } \\
\text { Swallow }\end{array}$} & 2013 & $\begin{array}{c}4.8 \pm 0.7 \\
(35)\end{array}$ & $\begin{array}{c}4.5 \pm 0.8 \\
(53)\end{array}$ & $\begin{array}{c}4.4 \pm 1.1 \\
(10)\end{array}$ & $\begin{array}{c}4.6 \pm 0.8 \\
(98)\end{array}$ \\
\hline & 2014 & $\begin{array}{c}4.8 \pm 0.5 \\
(46)\end{array}$ & $\begin{array}{c}4.7 \pm 0.6 \\
(68)\end{array}$ & $\begin{array}{c}4.7 \pm 0.8 \\
(13)\end{array}$ & $\begin{array}{c}4.8 \pm 0.6 \\
(127)\end{array}$ \\
\hline & 2015 & $\begin{array}{c}4.7 \pm 0.7 \\
(44)\end{array}$ & $\begin{array}{c}4.7 \pm 0.7 \\
(69)\end{array}$ & $\begin{array}{c}4.4 \pm 1.3 \\
(11)\end{array}$ & $\begin{array}{c}4.7 \pm 0.7 \\
(124)\end{array}$ \\
\hline & 2016 & $\begin{array}{c}4.8 \pm 0.8 \\
(32)\end{array}$ & $\begin{array}{c}4.5 \pm 0.8 \\
(45)\end{array}$ & $\begin{array}{c}4.5 \pm 0.5 \\
(6)\end{array}$ & $\begin{array}{c}4.6 \pm 0.8 \\
(83)\end{array}$ \\
\hline & Average & $\begin{array}{c}4.8 \pm 0.7 \\
(157)\end{array}$ & $\begin{array}{c}4.6 \pm 0.7 \\
(235)\end{array}$ & $\begin{array}{c}4.5 \pm 1.0 \\
(40)\end{array}$ & $\begin{array}{c}4.7 \pm 0.7 \\
(432)\end{array}$ \\
\hline \multirow[t]{5}{*}{$\begin{array}{l}\text { Tree } \\
\text { Swallow }\end{array}$} & 2013 & $\begin{array}{c}5.2 \pm 0.8 \\
(6)\end{array}$ & $\begin{array}{c}4.0 \pm 2.0 \\
(4)\end{array}$ & N/A & $\begin{array}{c}4.7 \pm 1.4 \\
(10)\end{array}$ \\
\hline & 2014 & $\begin{array}{c}5.6 \pm 0.6 \\
(14)\end{array}$ & $\begin{array}{c}4.9 \pm 0.8 \\
(25)\end{array}$ & $\begin{array}{c}4.8 \pm 0.5 \\
(4)\end{array}$ & $\begin{array}{c}5.1 \pm 0.8 \\
(43)\end{array}$ \\
\hline & 2015 & $\begin{array}{c}4.9 \pm 1.4 \\
(15)\end{array}$ & $\begin{array}{c}5.2 \pm 0.60 \\
(29)\end{array}$ & N/A & $\begin{array}{c}5.1 \pm 0.9 \\
(44)\end{array}$ \\
\hline & 2016 & $\begin{array}{c}5.6 \pm 0.9 \\
(23)\end{array}$ & $\begin{array}{c}5.4 \pm 0.7 \\
(32)\end{array}$ & N/A & $\begin{array}{c}5.5 \pm 0.8 \\
(55)\end{array}$ \\
\hline & Average & $\begin{array}{c}5.4 \pm 1.0 \\
(58)\end{array}$ & $\begin{array}{c}5.1 \pm 0.8 \\
(90)\end{array}$ & $\begin{array}{c}4.8 \pm 0.5 \\
(4)\end{array}$ & $\begin{array}{c}5.2 \pm 0.9 \\
(152)\end{array}$ \\
\hline
\end{tabular}

\section{Brood size at fledging variation}

In the full model for brood size at fledging, there was a significant species $\times$ year interaction $\left(F_{2,28}=5.4, P=0.01\right)$, but no other interactions were significant (Table A1.3 in Appendix 1). Therefore, we analyzed brood size at fledging by year (2014-2016), with species, habitat, and species $\times$ habitat as main effects, and laydate as a covariate. There was a significant difference in brood size at fledging between species in $2014\left(F_{1,46}=7.46, P<0.01\right)$ and $2016\left(F_{1,64}=4.59, P<0.05\right)$, but not in $2015\left(F_{1,60}=1.94, P\right.$ $>0.15$; no effect of habitat or species $\times$ habitat in any year, $P>$ 0.35). However, brood size was larger in Barn Swallows (4.6 \pm 0.6 chicks) than Tree Swallows (3.8 \pm 1.3 chicks) in 2014, whereas in 2016, brood size at fledging was smaller in Barn Swallows (3.5 \pm 1.1 chicks $)$ than Tree Swallows $(4.1 \pm 1.2$ chicks; Table 3$)$.

Table 3. Average brood size (number of chicks) for first broods of Barn Swallow and Tree Swallow for 2013 to 2016 across habitat types, habitat type average, and overall species averages. Values are mean brood size \pm standard deviation, with sample size in parentheses.

\begin{tabular}{lccccc}
\hline \hline & & \multicolumn{3}{c}{ Habitat type } & \\
\cline { 3 - 5 } Species & Year & Crop & Pasture & $\begin{array}{c}\text { Nonagric- } \\
\text { ultural }\end{array}$ & Average \\
\hline Barn & 2013 & $3.9 \pm 1.0$ & $4.0 \pm 0.8$ & $4.4 \pm 1.3$ & $4.1 \pm 1.0$ \\
Swallow & & $(10)$ & $(18)$ & $(7)$ & $(35)$ \\
& 2014 & $4.6 \pm 0.6$ & $4.5 \pm 0.6$ & $4.7 \pm 0.8$ & $4.6 \pm 0.6$ \\
& & $(19)$ & $(22)$ & $(10)$ & $(51)$ \\
& 2015 & $3.8 \pm 1.0$ & $4.1 \pm 0.9$ & $4.2 \pm 0.8$ & $4.0 \pm 0.9$ \\
& & $(13)$ & $(33)$ & $(5)$ & $(51)$ \\
& 2016 & $3.4 \pm 1.3$ & $3.5 \pm 1.0$ & $3.0 \pm 1.4$ & $3.5 \pm 1.1$ \\
& & $(18)$ & $(27)$ & $(2)$ & $(47)$ \\
& Average & $4.0 \pm 1.1$ & $4.0 \pm 0.9$ & $4.4 \pm 1.1$ & $4.0 \pm 1.0$ \\
Tree & & $(60)$ & $(100)$ & $(24)$ & $(184)$ \\
Swallow & 2013 & $3.3 \pm 0.6$ & N/A & N/A & $3.3 \pm 0.6$ \\
& & $(3)$ & & & $(3)$ \\
& 2014 & $3.7 \pm 1.4$ & $3.0 \pm 14$ & N/A & $3.8 \pm 1.3$ \\
& & $(6)$ & $(10)$ & & $(16)$ \\
& 2015 & $4.3 \pm 1.5$ & $4.4 \pm 0.9$ & N/A & $4.4 \pm 1.2$ \\
& & $(10)$ & $(15)$ & & $(25)$ \\
& 2016 & $4.4 \pm 0.9$ & $3.9 \pm 1.3$ & N/A & $4.1 \pm 1.2$ \\
& & $(10)$ & $(20)$ & & $(30)$ \\
& Average & $4.1 \pm 1.2$ & $4.1 \pm 1.2$ & N/A & $4.1 \pm 1.2$ \\
& & $(29)$ & $(45)$ & & $(74)$ \\
\hline
\end{tabular}

Fledging success was significantly different across years $\left(\chi_{3}^{2}=14\right.$, $P=0.003)$, but not between species $\left(\chi^{2}{ }_{1}=2.9, P=0.088\right)$ or for crop vs. pasture habitat $\left(\chi_{1}^{2}=0.37, P=0.54\right)$. Fledging success was lower in $2014\left(Z_{569}=-2.44, P=0.015\right), 2015\left(Z_{569}=-3.39\right.$, $P<0.001)$, and $2016\left(Z_{569}=-3.23, P=0.001\right)$ than in 2013 , with $72-78 \%$ of nests successfully fledging from $2014-2016$ vs. $90.1 \%$ of nests successfully fledging in 2013 .

For second broods, Barn Swallows had an average brood size of 3.42 ( \pm 1.12 chicks) across habitats and years.

\section{Habitat effects within species, including nonagricultural habitat}

For Barn Swallows, comparing crop, pasture, and nonagricultural habitat, lay date was independent of habitat $\left(F_{2,208}=1.61, P>\right.$ $0.20)$ and the habitat $\times$ year interaction $\left(F_{6,458}=0.78, P>0.50\right)$, but there was an effect of year $\left(F_{3,458}=3.89, P<0.01\right)$. In contrast, clutch size varied among habitats for Barn Swallows $\left(F_{2,184}=8.10\right.$, $P<0.001$; no effect of year or year $\times$ habitat, $P>0.40$ for both). Clutch size was larger in crop habitat $(4.8 \pm 0.7$ eggs $)$ than in pasture $(4.6 \pm 0.7 \mathrm{eggs}, P<0.05)$ and nonagricultural habitat $(4.5$ \pm 1.0 eggs, $P<0.05)$. Finally, for Barn Swallows, brood size at fledging was independent of habitat $\left(F_{2,76}=1.92, P>0.15\right)$ and 
the habitat $\times$ year interaction $\left(F_{6,56}=0.33, P>0.90\right)$, but there was an effect of year $\left(F_{3,56}=6.93, P<0.001\right)$.

For Tree Swallows, data were available for all three habitats only in 2014. There was no effect of habitat on laying date $\left(F_{2,57}=0.90\right.$, $P=0.41)$ or brood size at fledging $\left(F_{1,17}=1.34, P>0.25\right)$. However, clutch size varied among habitats $\left(F_{2,52}=7.14, P<0.01\right)$. Clutch size was larger in crop habitat (5.4 \pm 1.0 eggs) than in pasture (5.1 \pm 0.8 eggs, $P<0.01)$ and nonagricultural habitat $(4.8 \pm 0.5$ eggs, $P<0.01)$.

\section{Insect abundance}

There was no effect of year $\left(F_{3,45}=0.69, P=0.5\right)$ and no year $\times$ habitat interaction $\left(F_{6,45}=0.99, P=0.44\right)$ on insect abundance (Fig. 4), but there was a main effect of habitat $\left(F_{2,45}=17.1, P<\right.$ $0.001)$. Pasture habitat had the highest mean insect abundance (170 \pm 35 insects/net), although it was not significantly different from that in crop habitat (116 \pm 37 insects/net), and the highest abundances sampled were all from the pasture habitat (Appendix 2). However, nonagricultural habitat had low insect abundance (10 $\pm 44 \mathrm{insects} / \mathrm{net})$, and was significantly lower than both pasture $\left(t_{45}=5.04, P<0.001\right)$ and crop habitat $\left(t_{45}=5.41, P<0.001\right)$. Diptera dominated the insect samples in all habitats ( $75 \%$; Table A1.8 in Appendix 1).

Fig. 4. Variation in total number of insects caught per net by habitat across 2013-2016. Crop: four locations, 28 total net/day; pasture: four locations, 28 total net/day; nonagricultural: three locations, 19 total net/day). Least squares means and standard errors. Covariates are net identity and location.

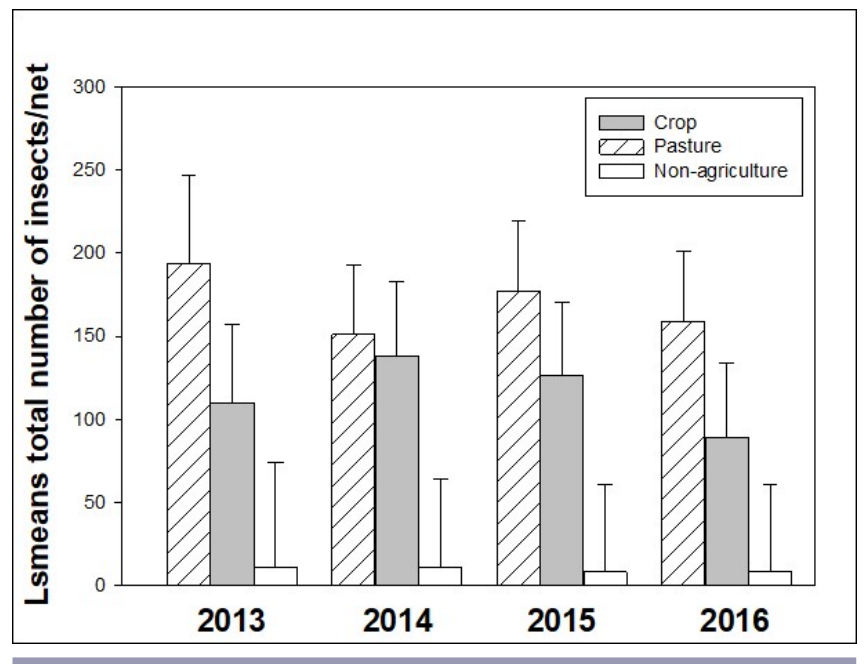

\section{Weather effects on phenology and breeding productivity}

The average temperature was warmest in 2016 and coolest in 2015 and varied significantly during Barn Swallows' 2-week $\left(F_{3,56}=\right.$ $3.18, P=0.031)$ and 4 -week pre-laying period $\left(F_{3,112}=5.33 P=\right.$ $0.002)$, and during Tree Swallows' 4-week pre-laying period $\left(F_{3,112}=5.84, P<0.001\right)$. The average temperature during chick rearing was warmest in 2015 and coolest in 2014 and varied significantly among years $\left(F_{3,116}=6.74, P<0.001\right)$. Average wind speed $\left(F_{3,116}=2.73, P=0.047\right)$ also varied significantly among years in the chick-rearing period (June) and was strongest in 2015 and weakest in 2013. There were no other differences in annual variation for the remaining weather variables among years, including average rainfall (Tables A1.5 and A1.6 in Appendix 1).

Comparing years with species and locations combined $(N=44$ for each species), average lay date varied significantly with average temperature in the 2-week pre-laying period $\left(F_{1,60}=4.67, P=\right.$ $0.035)$, but there was no species effect $\left(F_{1,60}=0.29, P=0.59\right)$ and no species $\times$ year interaction $\left(F_{1,60}=0.004, P=0.95\right)$. Similar results were obtained using the 4-week pre-laying period (Fig. 5; see Table A1.7 in Appendix 1). Average clutch size and brood size were independent of all weather metrics $(P>0.071$; see Table A1.7 in Appendix 1).

Fig. 5. Average lay date by average temperature $\left({ }^{\circ} \mathrm{C}\right)$ across sites (with years pooled) during the 4 -wk pre-laying period for Barn Swallows (dark grey) and Tree Swallows (light grey). Julian date $1=1$ January. Lines are linear regressions.

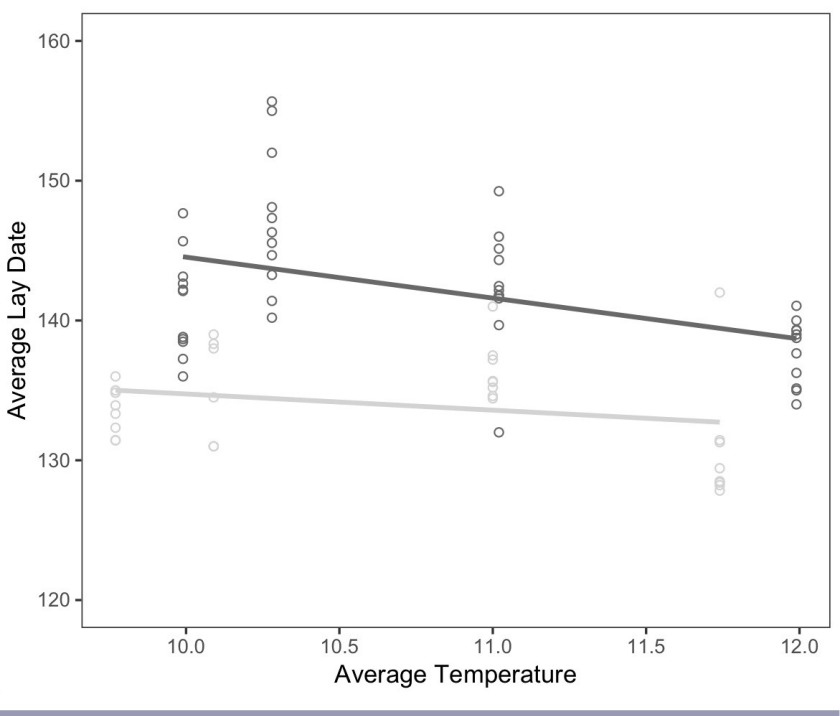

\section{DISCUSSION}

We compared the effects of weather and habitat on breeding phenology and breeding productivity in two co-occurring aerial insectivores. At the population level, Barn Swallows and Tree Swallows initiated laying at similar dates, despite differences in migratory biology, but Tree Swallows laid more synchronously after initiation of laying such that the mean lay date was earlier in all years, on average by $7.8 \mathrm{~d}$. Tree Swallows had larger clutches in crop habitat, independent of year, but only in one of four years in pasture habitat. There were also few differences in breeding productivity: brood size at fledging was higher in Barn Swallows in one year, but higher in Tree Swallows in another year. Similarly, there was no difference in fledging success between species. Thus, we found few differences in breeding phenology or breeding productivity between Barn and Tree Swallows breeding at the same locations, despite an a priori expectation of differences given the myriad of life-history differences of these two species. The only major difference, i.e., double-brooding in Barn Swallows, should buffer this species from population declines (even 
discounting lower post-natal survival of second-brood chicks). Pasture habitat had significantly greater insect abundance than nonagricultural habitat, but only marginally more than crop. Nonagricultural habitat had a greater diversity of insect types, whereas pasture habitat had the most Diptera species. However, these differences in prey were not reflected in marked differences in breeding productivity among habitats. When comparing across species and years, warmer spring temperatures were associated with earlier average lay dates, suggesting that both species have the capacity to adapt to variation in early season temperatures. However, given the relative similarity in breeding productivity that we observed, and given that the Barn Swallow is doublebrooded and therefore has higher reproductive potential, yet still has the greatest decline in the region, interspecies differences in population trends in this region could be driven by variation in survival during the post-fledging, migration, or wintering periods, rather than over the breeding period. In other populations with the same pattern of more steeply declining Barn Swallow vs. Tree Swallow trends, Imlay et al. (2018) also did not find much difference in nest success between Tree Swallows (74.6\%) and Barn Swallows (72.7\%) from 2006-2016, which is further evidence that causes of decline may be related to other parts of the life cycle.

We found that Tree Swallows bred on average one week earlier than Barn Swallows each year. The two species are generally classified as short- vs. long-distance migrants across North America (Brown and Brown 2020, Winkler et al. 2020), which could explain the variation in lay date between the two species. However, Tree Swallows migrate an average distance of $4295 \mathrm{~km}$ from the wintering grounds to Prince George, BC $(N=11$; Gow et al. 2019b), whereas Barn Swallows from Washington state migrate an average of $4528 \mathrm{~km}$ when returning to the breeding site $(N=9$; Hobson et al. 2015), suggesting relatively comparable migration distances for the two species (although there is a difference of approximately $680 \mathrm{~km}$ between Prince George, BC and Seattle, Washington). Because Barn Swallows in western North America have also been shown to winter closer to their breeding grounds (Hobson et al. 2015), the short- vs. longdistance migrant comparison is not necessarily true for individuals in this region, and other life history drivers are likely influencing lay date in these two species. For example, Barn Swallow migratory timing is thought to be highly heritable (Møller 2001b), whereas the timing of Tree Swallow migration is suggested to be influenced by temperature (Winkler et al. 2020). Furthermore, breeding latitude has been shown to affect the timing of breeding for Tree Swallows; specifically, birds breeding at lower latitudes have earlier first egg dates (Gow et al. 2019a). One other study that compared the reproductive biology of these two species in North America found the species' lay dates to be similar in New York (Ramstack et al.1998), although there could be regional differences given that another comparison by Imlay et al. (2018) found that Barn and Tree Swallows on the Atlantic coast of Canada initiate clutches approximately 1 week apart, despite advances of lay date. These differences suggest that variation in phenology between the two species is based on inherent differences between the species and is unlikely to be a cause of different population trends in this region.

Tree Swallows had larger clutches than Barn Swallows across all our study locations, with significantly larger clutches in crop habitat, and in pasture habitat in one year. However, both species had similar brood sizes at fledging across years and habitats such that Tree Swallows did not have a breeding performance advantage despite laying more eggs. We observed similar nestling mortality in both species due to predation, starvation, and overheating, which could account for similar brood sizes. Larger clutch size in Tree Swallows corresponds with other studies, albeit comparing birds at different geographical locations, e.g., Tree Swallows have an average clutch size of 5.9 eggs in Ontario (Hussell and Quinney 1987) and 5.2 eggs in southern Quebec (Ghilain and Bélisle 2008), whereas Barn Swallows have an average clutch size of 4.6 eggs across several American cities (Brown and Brown 2020). Imlay et al. (2018) also found that Tree Swallows have larger clutches (5.5 eggs) than Barn Swallows (4.6 eggs) over a 10-year period in the same region in eastern Canada. It is well documented that multibrooded species have different seasonal patterns of clutch size than single-brooded species (Williams 2012). Multibrooded species optimize clutch size over several breeding attempts and, typically, smaller clutches are laid at the beginning of the breeding season relative to later, maximum clutch sizes (Crick et al. 1993). This explanation is the most parsimonious for smaller clutch sizes in first breeding attempts in Barn Swallows compared to Tree Swallows. Therefore, it is likely that Barn Swallows have smaller clutch sizes in general or due to evolutionary life-history factors, but because there has been little comparative research of these two species when co-occurring in the same region under the same environmental conditions, this idea is difficult to confirm.

We found relatively little evidence for strong effects of habitat on reproduction in either species. There was no effect of natal habitat in any models for lay date, brood size at fledging, or fledging success. For clutch size, Tree Swallows had larger clutches compared with Barn Swallows in all four years in crop habitat, but only during one year in pasture habitat, suggesting a positive effect of crop habitat in terms of relative clutch size for Tree Swallows. However, within species, Barn Swallows had larger clutches in crop than pasture habitat, and Tree Swallows also had larger clutches in crop habitat, but only in one year. These results vary from some European studies of Barn Swallows; for example, Møller (2001a) found that Barn Swallow clutch size in Denmark was smaller in the absence of cattle than in their presence. Previous studies have suggested that breeding habitat can be important for both species' reproductive success, with some habitats of higher quality than others for reproductive output, particularly pasture and hayfields, contrary to our results (Ghilain and Bélisle 2008, Grüebler et al. 2010). Generally, livestock increases the abundance of the preferred type and size of aerial insect prey available for breeding aerial insectivores (Orlowski and Karg 2013), and aerial insects are found in higher abundances over pasture fields than other crop types such as cereals (Evans et al. 2007). The presence of livestock (including pigs, chickens, and cows) and manure heaps has been shown to increase the survival and annual output of nestlings in double-brooded pairs of Barn Swallows (Grüebler et al. 2010). In addition, nestling body mass was found to increase during the breeding season, when nestlings were in rooms with livestock, although nestling quality and brood size were not affected (Ambrosini et al. 2006). A higher proportion of both hayfields and pastures is found to increase the number of Tree Swallow fledglings and probability of successful fledging (Ghilain and Bélisle 2008). In addition, hayfields alone (not included with 
pasture or livestock) surrounding a breeding site positively affect Barn Swallow nestling mass and feather development (Sicurella et al. 2014), and Barn Swallow adults will selectively forage over hayfields within close proximity to breeding areas $(<400 \mathrm{~m}$; Ambrosini et al. 2002). However, Barn Swallow fledglings use crop habitat more relative to its availability in our study region (Boynton et al. 2020), and proximity to row crops was positively correlated to nestling body condition and number of young fledged in southern Ontario (Kusack et al. 2020), suggesting that crop habitat in our study region may be higher in quality than in other areas. Although we found only minor effects of habitat type at the local scale on measures of nesting success, we did not measure the effect of landscape-scale habitat in our study, which can affect productivity in some species, including the Tree Swallow (Ghilain and Bélisle 2008).

Despite a lack of habitat effect on breeding productivity, when we examined insect availability and occurrence, we did find variation across habitats. Similar to European studies, which indicate that aerial insect availability and abundance is higher over livestock (Evans et al. 2007, Orlowski and Karg 2013), our data show that pasture habitat had the highest total number of insects. This result was significantly different than in nonagriculture habitats but not in crop habitat. Pasture habitat also had a higher occurrence of Diptera species, but nonagriculture locations had a greater diversity of insect orders. Although our insect data suggest greater benefits of pasture habitat, there is limited evidence that habitat affects breeding productivity for either Barn Swallows or Tree Swallows. Ultimately, this result indicates that breeding productivity in our region is not limited by aerial insect diversity or abundance and suggests that other factors outside of the breeding period cause a greater decline in Barn Swallows than in Tree Swallows.

Over our 4-year study period (2013-2016), average temperature and average wind were highest in June 2015, and the lowest average temperatures of the 2- and 4-wk pre-breeding period also occurred in 2015. This annual variation in wind and temperature, however, did not appear to affect either Tree Swallow or Barn Swallow clutch size or breeding productivity (brood size at fledging and fledging success) given that there was no significant annual variation in breeding variables in 2015 . However, our study was limited to only four years, which could result in local weather conditions not affecting demographic variables for either species. Recent studies of Tree Swallows have found a decrease in nestling body mass with an increase in mean rainfall during the nestling period (Cox et al. 2019) and poor fledging success associated with poor weather conditions (low temperatures, abundant precipitation; Cox et al. 2020), suggesting that local weather conditions can affect this species on the breeding grounds. However, Weegman et al. (2017) also found no effect of local weather conditions on various population dynamic parameters for Tree Swallows nesting near Prince George, BC. North American studies of weather condition effects on Barn Swallow demographic variables have focused on annual climatic indices (see García-Pérez et al. 2014), and, to our knowledge, none have focused on local weather conditions. However, a recent study in Cardiff, Wales found that daily Barn Swallow nestling body mass declined with temperature, and this relationship was stronger with lower wind speed and greater rainfall (Facey et al. 2020). Overall, we found that Tree Swallows and Barn Swallows showed similar responses to local weather conditions in terms of breeding phenology over the four years of our study.

Our results show that Barn Swallows have smaller clutches, later average lay dates, and are less synchronous in their breeding timing compared to Tree Swallows. Variation in foraging habitat during the breeding season could explain these minor interspecies differences (particularly clutch size) because Barn Swallows could be consuming lower quality or fewer aerial insect prey because of a preference for different foraging habitat, specifically open fields and pasture, compared to Tree Swallows, which tend to forage near aquatic systems. Given the higher propensity for double brooding and no differences in brood size or fledging success, it would appear that Barn Swallows in this region may in fact have higher annual productivity than Tree Swallows, suggesting that breeding productivity is not related to differences in regional population trends between the species. Multiple demographic rates could also be driving the variation in population trajectories, and a more comprehensive demographic study of both species could better elucidate survival and reproductive rate, as shown in studies of Tree Swallows in Ontario (Cox et al. 2018) and of Barn Swallows (Schaub et al. 2015). Alternatively, different survival rates during the post-fledging period, during migration, or on the wintering grounds may be driving variation in population trends of these two species. We acknowledge that it is difficult to identify the demographic processes leading to population decline when only considering measures of reproductive timing, investment, and success. Thus, although we suggest that processes occurring outside the breeding season are likely important, based on our results, other processes occurring on the breeding grounds may be equally or more important, e.g., survival upon arrival to breeding areas, breeding dispersal, and early post-fledging survival (see Boynton et al. 2020). Our research is one of the few studies that has compared co-occurring aerial insectivores on the breeding grounds, and we recommend that further research is necessary to provide a better understanding of interspecies differences, given the differing population trends. Specifically, comparisons between Barn Swallows and Tree Swallows during the post-fledging stage and exploration into each species' annual survival are needed to elucidate drivers of interspecies variation in population trends.

Responses to this article can be read online at: https://www.ace-eco.org/issues/responses.php/2001

\section{Author Contributions:}

C.K.B. conducted the literature review, performed the fieldwork, collected and analyzed data, and drafted the manuscript. O.C.L. performed the fieldwork and edited the manuscript. N.M. conceived the idea, co-supervised the project, and edited the manuscript. T.W. co-supervised the project, analyzed insect data, and edited the manuscript.

\section{Acknowledgments:}

We acknowledge and thank all of the landowners involved in this project for allowing us to monitor Barn and Tree Swallows on their 
property. We thank Jessie Russell, Torin Heavyside, and Brynn Roach, who were part of the dedicated field team. Funding was provided by Environment and Climate Change Canada, with support from the Department of Biology, Simon Fraser University, including scholarship support from Simon Fraser University.

\section{LITERATURE CITED}

Ambrosini, R., A. M. Bolzern, L. Canova, S. Arieni, A. P. Møller, and N. Saino. 2002. The distribution and colony size of barn swallows in relation to agricultural land use. Journal of Applied Ecology 39(3):524-534. https://doi.org/10.1046/j.1365-2664.2002.00721. $\mathrm{X}$

Ambrosini, R., R. P. Ferrari, R. Martinelli, M. Romano, and N. Saino. 2006. Seasonal, meteorological, and microhabitat effects on breeding success and offspring phenotype in the barn swallow, Hirundo rustica. Écoscience 13(3):298-307. https://doi.org/10.2980/ i1 195-6860-13-3-298.1

Benton, T. G., D. M. Bryant, L. Cole, and H. Q. P. Crick. 2002. Linking agricultural practice to insect and bird populations: a historical study over three decades. Journal of Applied Ecology 39(4):673-687. https://doi.org/10.1046/j.1365-2664.2002.00745.x

Boynton, C. K., N. A. Mahony, and T. D. Williams. 2020. Barn Swallow (Hirundo rustica) fledglings use crop habitat more frequently in relation to its availability than pasture and other habitat types. Condor 122(2):duz067. https://doi.org/10.1093/ condor/duz067

Brown, M. B., and C. R. Brown. 2020. Barn Swallow (Hirundo rustica), version 1.0. In P. G. Rodewald, editor. Birds of the world. Cornell Lab of Ornithology, Ithaca, New York, USA. https://doi. org/10.2173/bow.barswa.01

Campbell, R. W., N. K. Dawe, I. McTaggart-Cowan, J. M. Cooper, G. W. Kaiser, M. C. E. McNall, an G. E. J. Smith. 1997. Birds of British Columbia. Volume 3: passerines: flycatchers through vireos. UBC Press, Vancouver, Canada.

Cox, A. R., R. J. Robertson, B. C. Fedy, W. B. Rendell, and F. Bonier. 2018. Demographic drivers of local population decline in tree swallows (Tachycineta bicolor) in Ontario, Canada. Condor 120(4):842-851. https://doi.org/10.1650/CONDOR-18-42.1

Cox, A. R., R. J. Robertson, Á. Z. Lendvai, K. Everitt, and F. Bonier. 2019. Rainy springs linked to poor nestling growth in a declining avian aerial insectivore (Tachycineta bicolor). Proceedings of the Royal Society B 286(1898):20190018. https:// doi.org/10.1098/rspb.2019.0018

Cox, A. R., R. J. Robertson, W. B. Rendell, and F. Bonier. 2020. Population decline in tree swallows (Tachycineta bicolor) linked to climate change and inclement weather on the breeding ground. Oecologia 192:713-722. https://doi.org/10.1007/s00442-020-04618-8

Crick, H. Q. P., D. W. Gibbons, and R. D. Magrath. 1993. Seasonal changes in clutch size in British birds. Journal of Animal Ecology 62(2):263-273. https://doi.org/10.2307/5357

Evans, K. L., J. D. Wilson, and R. B. Bradbury. 2007. Effects of crop type and aerial invertebrate abundance on foraging barn swallows Hirundo rustica. Agriculture, Ecosystems and Environment 122(2):267-273. https://doi.org/10.1016/j.agee.2007.01.015

Facey, R. J., J. O. Vafidis, J. A. Smith, I. P. Vaughan, and R. J. Thomas. 2020. Contrasting sensitivity of nestling and fledgling Barn Swallow Hirundo rustica body mass to local weather conditions. Ibis 162(4):1163-1174. https://doi.org/10.1111/ ibi. 12824

García-Pérez, B., K. A. Hobson, G. Albrecht, M. D. Cadman, and A. Salvadori. 2014. Influence of climate on annual survival of barn swallows (Hirundo rustica) breeding in North America. Auk 131(3):351-362. https://doi.org/10.1642/AUK-13-145.1

Ghilain, A., and M. Bélisle. 2008. Breeding success of tree swallows along a gradient of agricultural intensification. Ecological Applications 18(5):1140-1154. https://doi.org/10.1890/07-1107.1

Government of Canada. 2017. Order amending Schedule 1 to the Species at Risk Act. SOR/2017-229. Canada Gazette 151(23). [online] URL: http://www.gazette.gc.ca/rp-pr/p2/2017/2017-11-15/ html/sor-dors229-eng.html

Government of Canada. 2019. Historical data. Meteorological Service of Canada, Environment and Climate Change Canada, Gatineau, Canada. [online] URL: https://climate.weather.gc.ca/ historical_data/search_historic_data_e.html

Gow, E. A., L. Burke, D. W. Winkler, S. M. Knight, D. W. Bradley, R. G. Clark, M. Bélisle, L. L. Berzins, T. Blake, E. S. Bridge, R. D. Dawson, P. O. Dunn, D. Garant, G. Holroyd, A. G. Horn, D. J. T. Hussell, O. Lansdorp, A. J. Laughlin, M. L. Leonard, F. Pelletier, D. Shutler, L. Siefferman, C. M. Taylor, H. Trefry, C. M. Vleck, D. Vleck, L. A. Whittingham, and D. R. Norris. 2019a. A range-wide domino effect and resetting of the annual cycle in a migratory songbird. Proceedings of the Royal Society B 286 (1894):20181916. https://doi.org/10.1098/rspb.2018.1916

Gow, E. A., S. M. Knight, D. W. Bradley, R. G. Clark, D. W. Winkler, M. Bélisle, L. L. Berzins, T. Blake, E. S. Bridge, L. Burke, R. D. Dawson, P. O. Dunn, D. Garant, G. Holroyd, A. G. Horn, D. J. T. Hussell, O. Lansdorp, A. J. Laughlin, M. L. Leonard, F. Pelletier, D. Shutler, L. Siefferman, C. M. Taylor, H. Trefry, C. M. Vleck, D. Vleck, L. A. Whittingham, and D. R. Norris. $2019 b$. Effects of spring migration distance on Tree Swallow reproductive success within and among flyways. Frontiers in Ecology and Evolution 7:380. https://doi.org/10.3389/fevo.2019.00380

Grüebler, M. U., F. Korner-Nievergelt, and J. von Hirschheydt. 2010. The reproductive benefits of livestock farming in barn swallows Hirundo rustica: quality of nest site or foraging habitat? Journal of Applied Ecology 47(6):1340-1347. [online] URL: https://www.jstor.org/stable/40958964

Hallmann, C. A., R. P. B. Foppen, C. A. M. van Turnhout, H. de Kroon, and E. Jongejans. 2014. Declines in insectivorous birds are associated with high neonicotinoid concentrations. Nature 511:341-343. https://doi.org/10.1038/nature13531

Hobson, K. A., K. J. Kardynal, S. L. Van Wilgenburg, G. Albrecht, A. Salvadori, M. D. Cadman, F. Liechti, and J. W. Fox. 2015. A continent-wide migratory divide in North American breeding barn swallows (Hirundo rustica). Plos One 10(6): e0129340. https://doi.org/10.1371/journal.pone.0129340 
Hussell, D. J. T., and T. E. Quinney. 1987. Food abundance and clutch size of tree swallows Tachycineta bicolor. Ibis 129 (S1):243-258. https://doi.org/10.1111/j.1474-919X.1987.tb03204. $\mathrm{X}$

Imlay, T. L., J. M. Flemming, S. Saldanha, N. T. Wheelwright, and M. L. Leonard. 2018. Breeding phenology and performance for four swallows over 57 years: relationships with temperature and precipitation. Ecosphere 9(4):e02166. https://doi.org/10.1002/ ecs 2.2166

Knight, S. M., D. W. Bradley, R. G. Clark, E. A. Gow, M. Bélisle, L. L. Berzins, T. Blake, E. S. Bridge, L. Burke, R. D. Dawson, P. O. Dunn, D. Garant, G. L. Holroyd, D. J. T. Hussell, O. Lansdorp, A. J. Laughlin, M. L. Leonard, F. Pelletier, D. Shutler, L. Siefferman, C. M. Taylor, H. E. Trefry, C. M. Vleck, D. Vleck, D. W. Winkler, L. A. Whittingham, and D. R. Norris. 2018. Constructing and evaluating a continent-wide migratory songbird network across the annual cycle. Ecological Monographs 88(3):445-460. https://doi.org/10.1002/ecm.1298

Kusack, J. W., G. W. Mitchell, D. R. Evans, M. D. Cadman, and K. A. Hobson. 2020. Effects of agricultural intensification on nestling condition and number of young fledged of barn swallows (Hirundo rustica). Science of the Total Environment 709:136195. https://doi.org/10.1016/j.scitotenv.2019.136195

McClenaghan, B., E. Nol, and K. C. R. Kerr. 2019. DNA metabarcoding reveals the broad and flexible diet of a declining aerial insectivore. Auk 136(1):uky003. https://doi.org/10.1093/ auk/uky003

Michel, N. L., A. C. Smith, R. G. Clark, C. A. Morrissey, and K. A. Hobson. 2016. Differences in spatial synchrony and interspecific concordance inform guild-level population trends for aerial insectivorous birds. Ecography 39:774-786. https://doi. org/10.1111/ecog.01798

Møller, A. P. 2001a. The effect of dairy farming on barn swallow Hirundo rustica abundance, distribution and reproduction. Journal of Applied Ecology 38(2):378-389. https://doi. org/10.1046/j.1365-2664.2001.00593.X

Møller, A. P. 2001b. Heritability of arrival date in a migratory bird. Proceedings of the Royal Society B 268(1463):203-206. https://doi.org/10.1098/rspb.2000.1351

Morales Fernaz, J., L. Schifferli, and M. U. Grüebler. 2012. Ageing nestling barn swallows Hirundo rustica: an illustrated guide and cautionary comments. Ringing and Migration 27 (2):65-75. https://doi.org/10.1080/03078698.2012.747587

Nebel, S., A. Mills, J. D. McCracken, and P. D. Taylor. 2010. Declines of aerial insectivores in North America follow a geographic gradient. Avian Conservation and Ecology 5(2):1. https://doi.org/10.5751/ACE-00391-050201

Nocera, J. J., J. M. Blais, D. V. Beresford, L. K. Finity, C. Grooms, L. E. Kimpe, K. Kyser, N. Michelutti, M. W. Reudink, and J. P. Smol. 2012. Historical pesticide applications coincided with an altered diet of aerially foraging insectivorous chimney swifts. Proceedings of the Royal Society B 279(1740):3114-3120. https:// doi.org/10.1098/rspb.2012.0445

North American Bird Conservation Initiative Canada. 2019. The state of Canada's birds 2019. Canadian Wildlife Service,
Environment and Climate Change Canada, Gatineau, Canada. [online] URL: http://nabci.net/wp-content/uploads/2019-Stateof-Canadas-Birds-1.pdf

Orłowski, G., and J. Karg. 2013. Partitioning the effects of livestock farming on the diet of an aerial insectivorous passerine, the barn swallow Hirundo rustica. Bird Study 60(1):111-123. https://doi.org/10.1080/00063657.2012.748717

Paquette, S. R., D. Garant, F. Pelletier, and M. Bélisle. 2013. Seasonal patterns in Tree Swallow prey (Diptera) abundance are affected by agricultural intensification. Ecological Applications 23(1):122-133. https://doi.org/10.1890/12-0068.1

Paquette, S. R., F. Pelletier, D. Garant, and M. Bélisle. 2014. Severe recent decrease of adult body mass in a declining insectivorous bird population. Proceedings of the Royal Society B 281(1786):20140649. https://doi.org/10.1098/rspb.2014.0649

Pinheiro, J., D. Bates, S. DebRoy, D. Sarkar, S. Heisterkamp, B. van Willigen, and J. Ranke. 2020. nlme: linear and nonlinear mixed effects models. Version 3.1-148. R package. [online] URL: https://CRAN.R-project.org/package=nlme

R Core Team. 2018. R: a language and environment for statistical computing. R Foundation for Statistical Computing, Vienna, Austria. [online] URL: https://www.R-project.org/

Ramstack, J. M., M. T. Murphy, and M. R. Palmer. 1998. Comparative reproductive biology of three species of swallows in a common environment. Wilson Bulletin 110(2):233-243. [online] URL: https://sora.unm.edu/sites/default/files/journals/ wilson/v110n02/p0233-p0243.pdf

Rosenberg, K. V., A. M. Dokter, P. J. Blancher, J. R. Sauer, A. C. Smith, P. A. Smith, J. C. Stanton, A. Panjabi, L. Helft, M. Parr, and P. P. Marra. 2019. Decline of the North American avifauna. Science 366(6461):120-124. https://doi.org/10.1126/science.aaw1313

RStudio Team. 2016. RStudio: integrated development for R. RStudio, Boston, Massachusetts, USA. [online] URL: http:// www.rstudio.com/

Schaub, M., J. von Hirschheydt, and M. U. Grüebler. 2015. Differential contribution of demographic rate synchrony to population synchrony in barn swallows. Journal of Animal Ecology 84(6):1530-1541. https://doi.org/10.1111/1365-2656.12423

Sicurella, B., M. Caprioli, A. Romano, M. Romano, D. Rubolini, N. Saino, and R. Ambrosini. 2014. Hayfields enhance colony size of the Barn Swallow Hirundo rustica in northern Italy. Bird Conservation International 24(1):17-31. https://doi.org/10.1017/ S095927091300021X

Smith, A. C., M.-A. R. Hudson, V. I. Aponte, and C. M. Francis. 2019. North American breeding bird survey - Canadian trends website. Data version 2017. Environment and Climate Change Canada, Gatineau, Canada. [online] URL: https://wildlifespecies.canada.ca/breeding-bird-survey-results

Smith, A. C., M.-A. R. Hudson, C. M. Downes, and C. M. Francis. 2015. Change points in the population trends of aerialinsectivorous birds in North America: synchronized in time across species and regions. Plos One 10(7):e0130768. https://doi. org/10.1371/journal.pone.0130768 
Spiller, K. J., and R. Dettmers. 2019. Evidence for multiple drivers of aerial insectivore declines in North America. Condor 121(2): duz010. https://doi.org/10.1093/condor/duz010

Triplehorn, C. A., N. F. Johnson, and D. J. Borror. 2005. Borror and DeLong's introduction to the study of insects. Seventh edition. Thompson Brooks/Cole, Belmont, California, USA.

Verhulst, S., J. H. van Balen, and J. M. Tinbergen. 1995. Seasonal decline in reproductive success of the great tit: variation in time or quality? Ecology 76(8):2392-2403. https://doi.org/10.2307/2265815

Weegman, M. D., T. W. Arnold, R. D. Dawson, D. W. Winkler, and R. G. Clark. 2017. Integrated population models reveal local weather conditions are the key drivers of population dynamics in an aerial insectivore. Oecologia 185:119-130. https://doi. org/10.1007/s00442-017-3890-8

Williams, T. D. 2012. Physiological adaptations for breeding in birds. Princeton University Press, Princeton, New Jersey, USA.

Winkler, D. W., K. K. Hallinger, D. R. Ardia, R. J. Robertson, B. J. Stutchbury, and R. R. Cohen. 2020. Tree Swallow (Tachycineta bicolor), version 1.0. In A. F. Poole, editor. Birds of the world. Cornell Lab of Ornithology, Ithaca, New York, USA. https://doi. org/10.2173/bow.treswa.01 


\section{Appendix 1}

Table A1.1. Results from linear mixed- effects model for each habitat (crop and pasture) separately with clutch size as the dependent variable, species and year as main effects, 2-way interactions, and with individual nest ID nested within location as a random effect (cs species*year+jegg).

$\begin{array}{lllll} & & \text { df } & \text { F } \\ \text { Crop } & \text { Species } & 1,130 & 27.403 & <0.0001 \\ & \text { Year } & 3,53 & 1.7 & <0.0001 \\ & \text { Lay Date } & 1,53 & 8.827 & 0.0045 \\ \text { Pasture } & \text { Species:Year } & 3,53 & 1.696 & 0.1790 \\ & \text { Species } & 1,181 & 21.232 & <0.0001 \\ & \text { Year } & 3,94 & 2.040 & 0.1135 \\ & \text { Lay Date } & 1,94 & 6.755 & 0.0109 \\ & \text { Species:Year } & 3,94 & 7.224 & 0.0002\end{array}$


Table A1.2. Results from linear mixed- effects model for each species (Barn Swallow and Tree Swallow) separately with clutch size as the dependent variable, with year and habitat (crop and pasture) as main effects, 2-way interactions, and with individual nest ID nested within location as a random effect (cs hab*year+jegg).

$\begin{array}{lllll} & & \text { df } & \text { F } & \text { P } \\ \text { Barn Swallow } & \text { Habitat } & 1,93 & 4.616 & 0.0343 \\ & \text { Year } & 3,76 & 1.14 & 0.3384 \\ & \text { Lay Date } & 1,76 & 11.903 & 0.0009 \\ \text { Tree Swallow } & \text { Habitat:Year } & 3,76 & 0.696 & 0.5576 \\ & \text { Habitat } & 1,68 & 2.617 & 0.1104 \\ & \text { Year } & 3,71 & 4.304 & 0.0076 \\ & \text { Lay Date } & 1,71 & 4.143 & 0.0455 \\ & \text { Habitat:Year } & 3,71 & 3.998 & 0.0109\end{array}$


Table A1.3. Results from linear mixed- effects model with brood size as the dependent variable, with species, habitat and year (20142016) as the main effects, all 2-way and 3-way interactions and with individual nest ID nested within location as a random effect (bs species*year*hab).

$\begin{array}{llll} & \text { df } & \text { F } & \text { P } \\ \text { Habitat } & 1,14 & 0.0713 & 0.8972 \\ \text { Species } & 1,148 & 0.8567 & 0.3562 \\ \text { Year } & 2,29 & 5.4186 & 0.0100 \\ \text { Habitat:Species } & 1,148 & 0.0607 & 0.8057 \\ \text { Habitat:Year } & 2,29 & 0.3652 & 0.6972 \\ \text { Species:Year } & 2,29 & 5.5317 & 0.0092 \\ \text { Habitat:Species:Year } & 2,29 & 0.8888 & 0.4220\end{array}$


Table A1.4. Annual variation in average temperature $\left({ }^{\circ} \mathrm{C}\right)$ across 4 years (2013-2016) calculated using ANOVA for the 2 week and 4 week pre-laying period for each species separately (Barn Swallow and Tree Swallow) and the chick rearing period for both species. Significant results are shown by bolded text.

\begin{tabular}{|c|c|c|c|c|c|c|}
\hline \multirow{5}{*}{ Barn Swallows } & Breeding period & Year & Estimate $\pm \mathrm{sd}$ & $\mathrm{df}$ & $\mathrm{F}$ & P-value \\
\hline & 2 Week Pre- & 2013 & $11.8 \pm 2.7$ & 3 & 3.1791 & 0.03087 \\
\hline & laying Period & 2014 & $12.0 \pm 1.9$ & 3 & 3.1791 & 0.03087 \\
\hline & & 2015 & $10.7 \pm 1.7$ & 3 & 3.1791 & 0.03087 \\
\hline & & 2016 & $13.1 \pm 2.0$ & 3 & 3.1791 & 0.03087 \\
\hline \multirow{9}{*}{ Tree Swallows } & 4 Week Pre- & 2013 & $10.3 \pm 2.7$ & 3 & 5.3329 & 0.001799 \\
\hline & laying Period & 2014 & $11.0 \pm 1.8$ & 3 & 5.3329 & 0.001799 \\
\hline & & 2015 & $10.0 \pm 1.7$ & 3 & 5.3329 & 0.001799 \\
\hline & & 2016 & $12.0 \pm 2.0$ & 3 & 5.3329 & 0.001799 \\
\hline & 2 Week Pre- & 2013 & $11.4 \pm 2.6$ & 3 & 1.6623 & 0.1855 \\
\hline & laying Period & 2014 & $11.7 \pm 2.2$ & 3 & 1.6623 & 0.1855 \\
\hline & & 2015 & $10.8 \pm 1.8$ & 3 & 1.6623 & 0.1855 \\
\hline & & 2016 & $12.5 \pm 1.8$ & 3 & 1.6623 & 0.1855 \\
\hline & 4 Week Pre- & 2013 & $10.1 \pm 2.6$ & 3 & 5.8357 & 0.0009667 \\
\hline \multirow{7}{*}{ Both } & laying Period & 2014 & $11.0 \pm 1.8$ & 3 & 5.8357 & 0.0009667 \\
\hline & & 2015 & $9.8 \pm 1.8$ & 3 & 5.8357 & 0.0009667 \\
\hline & & 2016 & $11.73 \pm 1.7$ & 3 & 5.8357 & 0.0009667 \\
\hline & Chick Rearing & 2013 & $16.3 \pm 2.0$ & 3 & 6.74 & 0.000313 \\
\hline & Period (June) & 2014 & $15.7 \pm 1.4$ & 3 & 6.74 & 0.000313 \\
\hline & & 2015 & $17.8 \pm 2.2$ & 3 & 6.74 & 0.000313 \\
\hline & & 2016 & $16.1 \pm 2.1$ & 3 & 6.74 & 0.000313 \\
\hline
\end{tabular}


Table A1.5. Annual variation in average wind speed (kilometre/hour) across 4 years (2013-2016) calculated using ANOVA for the 2 week and 4 week pre-laying period for each species separately (Barn Swallow and Tree Swallow) and the chick rearing period for both species. Significant results are shown by bolded text.

$\begin{array}{lllllll} & \text { Breeding period } & \text { Year } & \text { Estimate } \pm \text { sd } & \text { df } & \text { F } & \text { P-value } \\ \text { Barn Swallows } & \text { 2 Week Pre- } & 2013 & 15.6 \pm 9.0 & 3 & 0.4119 & 0.7451 \\ & \text { laying Period } & 2014 & 14.1 \pm 3.0 & 3 & 0.4119 & 0.7451 \\ & & 2015 & 14.2 \pm 4.0 & 3 & 0.4119 & 0.7451 \\ & & 2016 & 13.4 \pm 4.1 & 3 & 0.4119 & 0.7451 \\ & \text { 4 Week Pre- } & 2013 & 15.4 \pm 7.4 & 3 & 0.3819 & 0.7663 \\ & \text { laying Period } & 2014 & 15.0 \pm 3.8 & 3 & 0.3819 & 0.7663 \\ \text { Tree Swallows } & 2015 & 14.5 \pm 4.6 & 3 & 0.3819 & 0.7663 \\ & & 2016 & 14.0 \pm 3.3 & 3 & 0.3819 & 0.7663 \\ & & 2013 & 15.4 \pm 9.1 & 3 & 0.2618 & 0.8526 \\ & \text { 2 Week Pre- } & 2014 & 13.9 \pm 3.2 & 3 & 0.2618 & 0.8526 \\ & \text { laying Period } & 2015 & 14.5 \pm 4.3 & 3 & 0.2618 & 0.8526 \\ & & 2016 & 13.8 \pm 3.7 & 3 & 0.2618 & 0.8526 \\ & & 15.4 \pm 7.4 & 3 & 0.2906 & 0.8321 \\ \text { Both } & \text { 4 Week Pre- } & 2013 & 14.8 \pm 4.1 & 3 & 0.2906 & 0.8321 \\ & \text { laying Period } & 2014 & 14.4 \pm 4.6 & 3 & 0.2906 & 0.8321 \\ & & 2015 & 14.3 \pm 3.1 & 3 & 0.2906 & 0.8321 \\ & & \mathbf{1 2 . 6} \pm \mathbf{3 . 6} & \mathbf{3} & \mathbf{2 . 7 2 5 9} & \mathbf{0 . 0 4 7 3 5} \\ & \text { Chick Rearing } & \mathbf{2 0 1 3} & \mathbf{1 3 . 6} \pm \mathbf{3 . 5} & \mathbf{3} & \mathbf{2 . 7 2 5 9} & \mathbf{0 . 0 4 7 3 5} \\ & \text { Period (June) } & \mathbf{2 0 1 4} & \mathbf{1 5 . 3} \pm \mathbf{4 . 4} & \mathbf{3} & \mathbf{2 . 7 2 5 9} & \mathbf{0 . 0 4 7 3 5} \\ & & \mathbf{2 0 1 5} & \mathbf{1 3 . 9} \pm \mathbf{3 . 0} & \mathbf{3} & \mathbf{2 . 7 2 5 9} & \mathbf{0 . 0 4 7 3 5}\end{array}$


Table A1.6. Annual variation in average rainfall (millimeters) across 4 years (2013-2016) calculated using ANOVA for the 2 week and 4 week pre-laying period for each species separately (Barn Swallow and Tree Swallow) and the chick rearing period for both species. Significant results are shown by bolded text.

\begin{tabular}{lllllll} 
& Breeding period & Year & Estimate $\pm \mathrm{sd}$ & $\mathrm{df}$ & $\mathrm{F}$ & \multicolumn{1}{c}{ P-value } \\
Barn Swallows & 2 Week Pre- & 2013 & $0.2 \pm 0.7$ & 3 & 2.5399 & 0.066 \\
& laying Period & 2014 & $3.6 \pm 6.0$ & 3 & 2.5399 & 0.066 \\
& & 2015 & $2.6 \pm 4.6$ & 3 & 2.5399 & 0.066 \\
& & 2016 & $0.7 \pm 1.7$ & 3 & 2.5399 & 0.066 \\
& 4 Week Pre- & 2013 & $2.7 \pm 6.3$ & 3 & 1.887 & 0.1359 \\
& laying Period & 2014 & $3.7 \pm 6.0$ & 3 & 1.887 & 0.1359 \\
Tree Swallows & 2015 & $1.8 \pm 3.6$ & 3 & 1.887 & 0.1359 \\
& & 2016 & $0.8 \pm 1.8$ & 3 & 1.887 & 0.1359 \\
& & 2013 & $0.2 \pm 0.7$ & 3 & 2.6605 & 0.05687 \\
& 2 Week Pre- & 2014 & $3.6 \pm 6.0$ & 3 & 2.6605 & 0.05687 \\
& laying Period & 2015 & $2.9 \pm 4.6$ & 3 & 2.6605 & 0.05687 \\
& & 2016 & $0.7 \pm 1.7$ & 3 & 2.6605 & 0.05687 \\
& & 2013 & $2.8 \pm 6.3$ & 3 & 1.8734 & 0.1382 \\
Both & 4 Week Pre- & 2014 & $3.7 \pm 6.0$ & 3 & 1.8734 & 0.1382 \\
& laying Period & & $1.8 \pm 3.6$ & 3 & 1.8734 & 0.1382 \\
& & 2015 & $0.8 \pm 1.8$ & 3 & 1.8734 & 0.1382 \\
& & 2016 & $1.5 \pm 3.6$ & 3 & 1.4471 & 0.2327 \\
& Chick Rearing & 2013 & $1.2 \pm 2.7$ & 3 & 1.4471 & 0.2327 \\
& Period (June) & 2014 & $0.4 \pm 1.4$ & 3 & 1.4471 & 0.2327 \\
& & 2015 & $1.9 \pm 3.8$ & 3 & 1.4471 & 0.2327
\end{tabular}


Table A1.7. Results from linear mixed- effects model with average lay date as the dependent variable, with 2 week and 4 week prelaying temperatures and species as the main effects, and site as a random effect.

2 week Pre-laying

4 Week Pre-laying

\section{2 week Prey-Laying Temperature} Species

2 week Pre-Laying Temperature: Species 4 week Prey-Laying Temperature

Species

4 week Pre-Laying Temperature: Species

$\begin{array}{lll}\text { df } & \mathrm{F} & \mathrm{P} \\ 1,60 & 4.6704 & 0.0347 \\ 1,60 & 0.2909 & 0.5916 \\ 1,60 & 0.0039 & 0.9507 \\ 1,60 & 14.1136 & 0.0004 \\ 1,60 & 4.0835 & 0.0478 \\ 1,60 & 2.0178 & 0.1606\end{array}$


Table A1.8. Variation in taxonomic distribution of major prey Orders from sampling nets by habitat for only the chick-rearing period (13-18 June).

$\begin{array}{llll} & \text { Crop } & \text { Pasture } & \text { Non-agriculture } \\ \text { Total insects } & 3204 & 4975 & 246 \\ \text { Aranae } & 20 & 18 & 13 \\ & (0.6 \%) & (0.4 \%) & (5.3 \%) \\ \text { Coleoptera } & 45 & 51 & 9 \\ & (1.4 \%) & (1.0 \%) & (3.7 \%) \\ \text { Diptera } & 2414 & 3967 & 178 \\ & (75.3 \%) & (79.7 \%) & (72.4 \%) \\ \text { Heteroptera } & 643 & 781 & 30 \\ & (20.1 \%) & (15.7 \%) & (12.2 \%) \\ \text { Hymenoptera } & 45 & 113 & 1 \\ & (1.4 \%) & (2.3 \%) & (0.4 \%) \\ \text { Other } & 37 & 45 & 15 \\ & (1.2 \%) & (0.9 \%) & (6.1 \%)\end{array}$


Table A1.9. Variation in taxonomic distribution of major prey Orders from sampling nets over the duration of the study period by habitat.

$\begin{array}{llll} & \text { Crop } & \text { Pasture } & \text { Non-agriculture } \\ \text { Total insects } & 9764 & 13838 & 913 \\ \text { Aranae } & 61 & 87 & 48 \\ & (0.6 \%) & (0.6 \%) & (5.3 \%) \\ \text { Coleoptera } & 145 & 247 & 39 \\ & (1.5 \%) & (1.8 \%) & (4.3 \%) \\ \text { Diptera } & 6710 & 10315 & 594 \\ & (68.7 \%) & (74.5 \%) & (65.1 \%) \\ \text { Heteroptera } & 2545 & 2679 & 153 \\ & (26.1 \%) & (19.4 \%) & (16.8 \%) \\ \text { Hymenoptera } & 211 & 350 & 30 \\ & (2.2 \%) & (2.5 \%) & (3.3 \%) \\ \text { Other } & 92 & 160 & 49 \\ & (0.9 \%) & (1.2 \%) & (5.4 \%)\end{array}$


Appendix 2

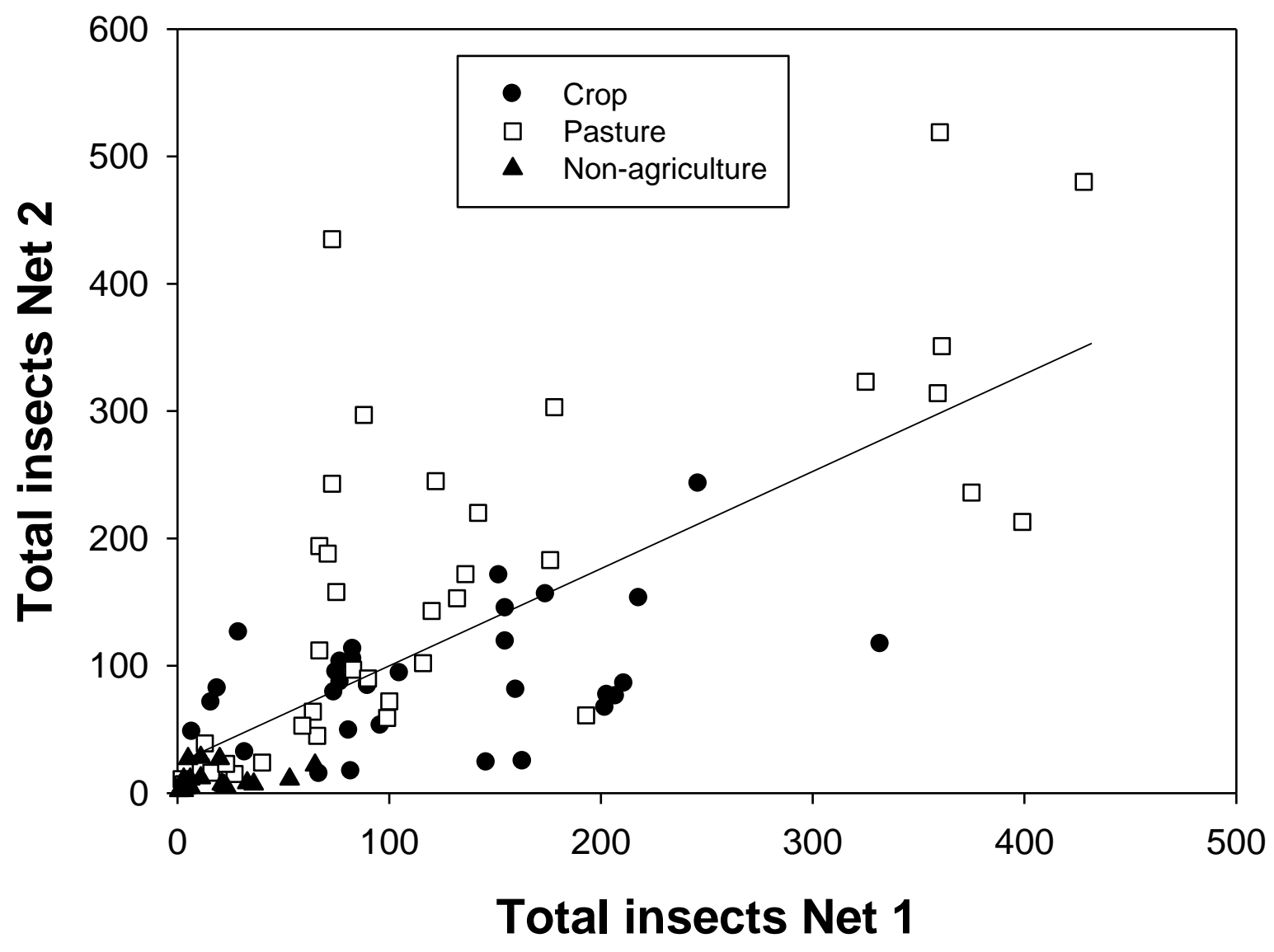

Figure A1.1. Comparison of total number of insects caught for 2 nets in each location by habitat type. 